\title{
PERPAJAKAN DI ERA EKONOMI DIGITAL: INDONESIA, INDIA DAN INGGRIS
}

\author{
Yanis Ulul Az'mi \\ Universitas Wijaya Kusuma Surabaya \\ Email: yanis_azmi@yahoo.com
}

\author{
ARTICLE INFO \\ Article History \\ JEL Classification \\ $\mathrm{H} 25, \mathrm{H} 26$

\section{Keywords:} \\ E-commerce tax, \\ Digital economic, \\ Marketplaces, and \\ Platform online
}

Received 1 December 2018

Revised 15 December 2018

Accepted 10 January 2019

\begin{abstract}
The development of new technology and diverse consumer demand has increased the digital retail industry today. This also affects the way buyers / consumers get the goods and services they want. Consumers turn to e-commerce and cellular to make purchases that are usually done physically. This change in shopping style has been driven largely due to the emergence of many market places and platforms. This change will also have effect on the taxation of the transaction. The Government of India applies the Equalization Levy Rules (EQL) scheme which is categorized as PNBP (Non-Tax Revenues). While in the United Kingdom there is a Diverted Provit Tax (DPT) scheme. Whereas Indonesia has no more specific rules, there is only a Circular (Surat Edaran) that regulates the Affirmation of Tax Regulations on eCommerce Transactions, namely SE / 62 / PJ / 2013 tax regulations e-commerce follows the income tax law and value added tax.
\end{abstract}

\section{PENDAHULUAN}

Bangkitnya ekonomi digital berkaitan dengan adanya revolusi industri 4.0. Revolusi industri 1.0 terjadi pada akhir abad ke-18. Industri diperkenalkan dengan fasilitas produksi mekanis menggunakan tenaga air dan uap. Revolusi industri 2.0 terjadi di awal abad ke-20. Revolusi industri ini menggunakan tenaga listrik sebagai sumber utama. Oleh karena itu, sudah mulai digunakannya konsep produksi masal. Pada akhir abad ke-20 ditengarai sebagai perdana munculnya revolusi industri 3.0 yaitu dimulai dengan adanya penggunaan elektronik dan teknologi informasi yang berguna untuk otomatisasi produksi (Okestrories 2018). Selanjutnya yang sekarang ini terjadi adalah revolusi industri 4.0 di mana semua mesin dihubungkan melalui sistem internet atau dikenal menggunakan cybersystems yang berfokus pada digitalisasi. Pergeseran inilah yang telah mengakibatkan munculnya ekonomi digital.

Ekonomi digital sekarang ini telah marak di mana secara spesifik mengarah pada transaksi barang dan jasa melalui media internet atau lebih di kenal dengan $e$ commerce. Ekonomi digital terdiri dari $e$ commerce, toko aplikasi, iklan online, layanan pembayaran online, could computing, dan platform (Juswanto dan Simms 2017). Ecommerce adalah penggunaan komputer dan jaringan komunikasi untuk melakukan prosesproses bisnis (McLeod 2007). Model bisnis di era ekonomi digital berbeda dengan bisnis yang konvensional. Contohnya pelaku bisnis digital memiliki markas atau gudang, tetapi tidak 
memiliki toko fisiknya. Pelaku bisnis hanya membuka atau membuat aplikasi yang akan dijadikan tempat berjualan bagi mereka.

Munculnya ekonomi digital ini menghasilkan layanan keunggulan yang inovatif, di antaranya cara transaksi bisnis yang lebih baik, baik layanan transfer maupun model bisnisnya, sehingga perusahaan sekarang ini didorong untuk bisa menyesuaikan diri agar dapat mendominasi bisnis di masa kini dan masa depan. Ini dibuktikan dengan munculnya toko-toko online (baik itu marketplaces maupun platform online) yang mulai merajalela di berbagai belahan dunia. Misalnya, Amazon yang merupakan toko online berasal dari Amerika yang memiliki kantor pusat di Seattle. Bermula dari menjual buku secara online, hingga sekarang ini Amazon memperluas bisnisnya untuk menjual semua produk trendi lain seperti DVD, barang elektronik dan yang lainnya. Situsnya memiliki lebih dari 250 miliar kunjungan per bulan. Alibaba merupakan perusahaan e-commerce China yang didirikan oleh Jack $\mathrm{Ma}$, menyediakan layanan penjualan melalui portal web dengan metode Costumer to Customer, business to customer dan business to business yang bertujuan untuk menghubungkan produsen Cina dengan pembeli di luar negeri. Alibaba menyediakan layanan pembayaran elektronik, mesin pencari belanja dan layanan komputasi awan datacentric. Contoh lainnya adalah Lazada yang didirikan di Indonesia tahun 2012 dan tempat pusat belanja online yang menawarkan berbagai macam jenis produk mulai dari elektronik, buku, mainan anak dan perlengkapan bayi, alat kesehatan dan produk kecantikan, peralatan rumah tangga, dan perlengkapan traveling dan olahraga (Ismail 2017).

Data pengguna internet di dunia mengalami peningkatan yang sangat signifikan. Data We Are Social dan Hootsuite mencatat penduduk yang ada di bumi yang telah terkoneksi dengan internet pada tahun 2018 mencapai 4 miliar. Angka tersebut menunjukkan bahwa tingkat penetrasi internet telah mencapai 52,96 persen dari total populasi dunia yang mencapai 7,59 miliar jiwa (Katadata 2018). Di Indonesia, tahun 2017 penetrasi pengguna internet sebesar 54,68 persen. Dari total populasi penduduk Indonesia 262 juta orang, yang mengakses internet sebanyak 143,26 juta (Asosiasi Penyelenggara Jasa Internet Indonesia 2016). Besarnya pengguna internet di dunia serta semakin merajalelanya platform dan marketplace memicu konsumen untuk berbelanja secara online. Pendapatan atas transaksi e-commerce tahun 2016 di Jepang sebesar $\$ 439,72$ milyar, Korea Selatan sebesar $\$ 143,13$ miliar, India sebesar $\$ 30,31$ miliar dan Indonesia sebesar $\$ 4,89$ miliar dengan jumlah onlie shopper mencapai 8,7 juta daring (Mahatma 2016). Pendapatan atas transaksi tersebut dapat membantu meningkatkan kontribusi pajak dari sektor $e$ commerce terhadap penerimaan negara. Oleh karena itu penulis ingin mengetahui pemajakan di beberapa negara lain misalnya India dan Inggris terkait regulasi perpajakan e-commerce.

\section{TELAAH TEORITIS}

\section{Bisnis di Era Ekonomi Digital}

OECD (2015) menggambarkan ekonomi digital sebagai hasil dari proses transformatif yang dibawa oleh teknologi informasi dan komunikasi (TIK), yang telah membuat teknologi lebih murah, lebih kuat, dan terstandarisasi secara luas, meningkatkan proses bisnis dan memperkuat inovasi di semua sektor ekonomi. Adanya ekonomi digital dapat menimbulkan keuntungan, yaitu informasi dan pengetahuan lebih mudah diakses oleh banyak orang. Jika teknologi dikelola dengan tepat, dapat mendorong inovasi yang selanjutnya dapat meningkatkan pendapatan dan meningkatkan kualitas hidup masyarakat. Bagi pebisnis e-commerce memiliki dampak positif berupa pengurangan biaya operasional dan dapat memperlebar pangsa pasar, sehingga keuntungan dapat dimaksimalkan dan lebih mudah dalam hal pengembangan bisnis (Widagdo 2016). 
Ekonomi digital ini dapat berdampak pada perekonomian suatu negara. Menurut Widagdo (2016) berkembangnya e-commerce akan memberi dorongan pada perekonomian wilayah yang lebih merata karena dengan semakin besarnya perputaran capital di suatu wilayah akan menyebabkan semakin pesatnya pertumbuhan ekonomi, serta transaksi yang lebih mudah selama 24 jam dan kemudahan proses pembayaran menyebabkan perputaran capital semakin cepat.

Ekonomi digital juga banyak tantangannya, di antaranya sebagian negara yang masyarakatnya belum bisa menggunakan atau memanfaatkan teknologi informasi, adanya masalah privasi dan keamanan cyber. Menurut Sandhausen (2008) bentuk-bentuk interaksi di dunia bisnis yaitu:

1. B2B (Business to Business) merupakan transaksi bisnis antara pelaku bisnis dengan pelaku bisnis lainnya. Dapat berupa kesepakatan spesifik yang mendukung kelancaran bisnis.

2. B2C (Business to Consumer) merupakan aktivitas yang dilakukan produsen kepada konsumen secara langsung tanpa melalui perantara.

3. C2C (Consumer to Consumer) merupakan aktivitas bisnis (penjualan) yang dilakukan oleh individu (konsumen) kepada individu (konsumen) lainnya.

4. $\mathrm{C} 2 \mathrm{~B}$ (Consumer to Business) merupakan $\mathrm{C} 2 \mathrm{~B}$ merupakan model bisnis di mana konsumen (individu) menciptakan dan membentuk nilai akan proses bisnis.

5. B2G (Busines to Government) merupakan turunan dari B2B, perbedaannya proses ini terjadi antara pelaku bisnis dan instansi pemerintah

6. G2C (Government to Consumer) merupakan hubungan atau interaksi antara pemerintah dengan masyarakat. Konsumen, dalam hal ini masyarakat, dapat dengan mudah menjangkau pemerintah sehingga memmperoleh kemudahan dalam pelayanan sehari-hari

\section{Jenis-jenis Transaksi di Era Ekonomi Digital}

Menurut Juswanto dan Simms (2017) ekonomi digital terdiri dari e-commerce, toko aplikasi, iklan online, layanan pembayaran online, could computing, dan platform. Sedangkan menurut Surat Edaran Nomor $\mathrm{SE} / 62 / \mathrm{PJ} / 2013$ e-commerce di bagi menjadi empat, yaitu:

1. Online Marketplace adalah kegiatan menyediakan tempat kegiatan usaha berupa toko internet sebagai Online Marketplace Merchant untuk menjual barang dan/atau jasa. Model transaksi ini, ada imbalan, dalam bentuk rent fee atau registration fee, atas jasa penyediaan tempat dan/atau waktu memajang iklan barang dan/atau jasa dan melakukan penjualan di toko internet melalui mal internet. Selain itu, ada sejumlah uang yang dibayarkan oleh Online Market place Merchant ke penyelenggara Online Marketplace sebagai komisi atas jasa perantara pembayaran atas penjualan barang dan/atau jasa. 


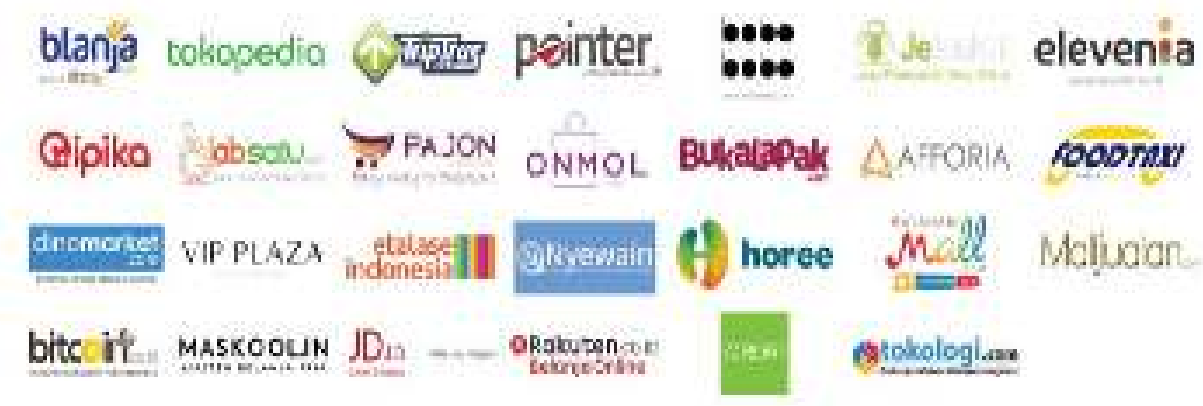

Gambar 1 Marketplace

Sumber: Asosiasi E-Commerce Indonesia

2. Classified Ads adalah kegiatan menyediakan tempat dan/atau waktu untuk memajang iklan barang dan/atau jasa yang dilakukan oleh pengiklan melalui situs yang disediakan oleh Penyelenggaran Classified Ads.
Kemudian pengiklan membayar sejumlah uang sebagai transaction fee kepada penyelenggara Classified Ads yang merupakan objek PPh dan PPN.

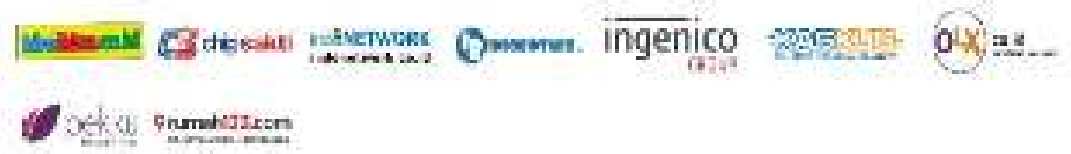

Gambar 2 Classified Ads

Sumber: Asosiasi E-Commerce Indonesia

3. Daily Deals mirip dengan Online

Marketplace namun, alat pembayaran yang

digunakan berupa voucher.

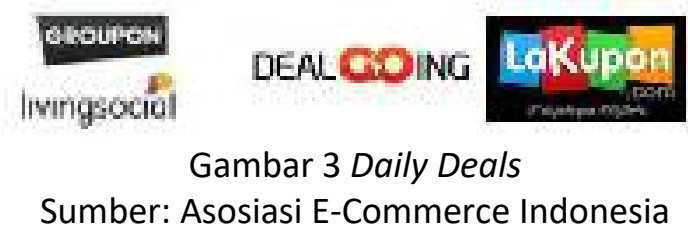

4. Online Retail adalah kegiatan menjual barang dan/atau jasa yang dilakukan secara langsung oleh penyelenggara Online Retail kepada pembeli di situs Online Retail. 


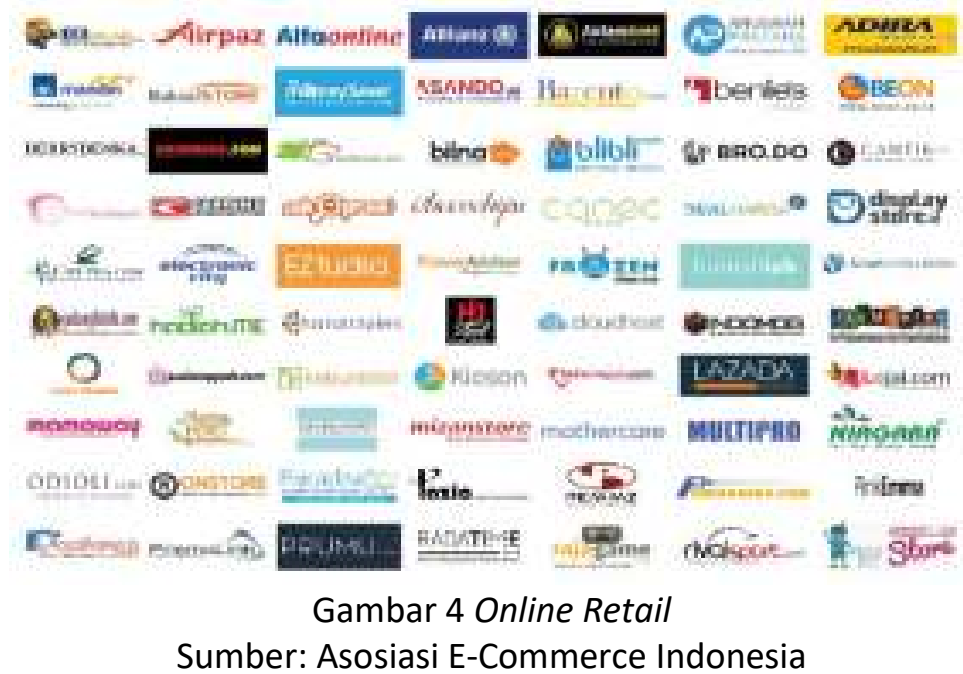

Lebih lanjut Pradana (2015) mengklasifikasikan bisnis e-commerce menjadi enam, yaitu:

1. Listing/Iklan baris merupakan sebuah platform dimana seseorang dapat memasang barang dagangan secara gratis

2. Online MarketPlace merupakan sebuah tempat (website) yang mempromosikan barang dagangan sekaligus memberikan fasilitas transaksi uang secara online.

3. Shopping Mall. Hampir sama dengan marketplace, namun yang bisa berjualan yaitu penjual atau brand ternama (bermerk). Hal ini dikarenakan verifikasinya yang ketat.

4. Toko Online merupakan sebuah toko online yang mempunyai alamat website sendiri. Sehingga penjual dapat menjual produknya secara online kepada pembeli.

5. Toko Online di media sosial yaitu penjual yang menggunakan situs media sosial contohnya Instagram dan Facebook untuk memperjual belikan produknya

6. Jenis-jenis website Crowdsourcing dan crowdfunding yaitu pemakaian website sebagai platform untuk mengumpulkan orang dengan kemampuan yang sama atau untuk penggalangan dana secara online.

\section{METODE PENELITIAN}

Penulisan artikel ini menggu-nakan metode penelitian kualitatif. Pengumupulan data menggunakan studi literatur. Penelitian dilakukan di negara Indonesia, India, dan Inggris. Objek penelitian adalah sistem perpajakan atas transaksi e-commerce. Jenis data yang digunakan merupakan data sekunder berupa peraturan perpajakan, publikasi resmi di website ketiga negara maupun dari lembaga international, dokumen yang mendukung dan hasil penelitian terdahulu dengan menganalisis beberapa jurnal dengan tema perpajakan di Era Ekonomi digital atau pemajakan dalam ecommerce. Data literatur tersebut dikumpulkan kemudian dianalisis dan dibandingkan antara ketiga negara tersebut.

\section{HASIL DAN PEMBAHASAN Perpajakan di Indonesia}

Perpajakan terkait dengan pajak Ecommerce di Indonesia tidak ada undangundang yang mengatur secara spesifik, hanya ada Surat Edaran (SE) yang mengatur Penegasan Ketentuan Perpajakan Atas Transaksi e-Commerce yaitu SE/62/PJ/2013. Direktur Jenderal Pajak dalam Surat Edaran Nomor SE/62/PJ/2013 tentang Penegasan Ketentuan Perpajakan Atas Transaksi $e$ commerce yang menegaskan tidak ada perbedaan perlakuan perpajakan antara 
Yanis Ulul Az'mi: Perpajakan di Era...

transaksi e-commerce dan transaksi perdagangan dan/atau jasa lainnya. Oleh karena itu peraturan pajak e-commerce mengikuti undang-undang pajak penghasilan dan juga pajak pertambahan nilai. Berikut ini aspek pemajakan transaksi e-commerce di Indonesia berdasarkan SE/62/PJ/2013:

\section{Online Marketplace}

a. Pengenaan PPh dari Transaksi Online Marketplace

1) Jasa Penyediaan Tempat dan/atau Waktu

Obyek PPh: Penghasilan dari jasa penyediaan tempat dan/ atau waktu dalam media lain untuk penyampaian informasi.

Subyek Pajak: Orang pribadi atau badan yang memperoleh penghasilan dari jasa penye-diaan tempat dan/atau waktu dalam media lain untuk pen-yampaian informasi

Tarif: Untuk Penyelenggara Online Marketplace sebagai penyedia jasa yang pengha-silannya tidak dikenai pajak yang bersifat final, tarif PPh Pasal 17 diterapkan atas Penghasilan Kena Pajak

Pemotongan: Apabila Online Marketplace Merchant sebagai pengguna jasa adalah Wajib Pajak Orang Pribadi atau Badan yang ditunjuk sebagai pemo-tong PPh, maka pengguna jasa tersebut wajib melakukan pemotongan PPh Pasal 23, Pasal 21, atau Pasal 26

2) Penjualan Barang dan/atau Jasa

Obyek PPh: Penghasilan dari penjualan barang dan/atau penyediaan jasa merupakan objek PPh

Subyek Pajak: Orang pribadi atau badan yang memperoleh penghasilan dari penjualan barang dan/atau penyediaan Jasa

Tarif: Untuk pihak Online Marketplace Merchant sebagai penjual barang atau penyedia jasa dalam Online Marketplace yang penghasilannya tidak dikenai pajak yang bersifat final, tarif PPh Pasal 17 diterapkan atas Penghasilan Kena Pajak

Pemotongan: Apabila Pembeli barang atau pengguna jasa adalah Wajib Pajak Orang Pribadi atau Badan yang ditunjuk sebagai pemotong/ pemungut PPh, maka Pembeli barang atau pengguna jasa tersebut wajib melakukan pemotongan/pemungutan PPh

3) Penyetoran Hasil Penjualan Kepada Online Marketplace Merchant Oleh Penyelenggara Online Marketplace

Obyek PPh: Penyetoran hasil Penjualan Kepada Online Marketplace Merchant Oleh Penyelenggara Online Market place Subyek Pajak: Penghasilan dari jasa perantara pembayaran merupakan objek PPh yang wajib dilakukan pemotongan PPh Pasal 23, Pasal 21, atau Pasal 26

Tarif: Untuk pihak Penyeleng-gara Online Marketplace sebagai penyedia jasa yang penghasilannya tidak dikenai pajak yang bersifat final, tarif PPh Pasal 17 diterapkan atas Penghasilan Kena Pajak

Pemotongan: Apabila Online Marketplace Merchant sebagai pengguna jasa adalah Wajib Pajak Orang Pribadi atau Badan yang ditunjuk sebagai pemo-tong PPh, maka pengguna jasa tersebut wajib melakukan pemotongan PPh Pasal 23, Pasal 21, atau Pasal 26 sesuai dengan ketentuan yang berlaku

b. Pengenaan PPN dari Transaksi Online Marketplace

1) Jasa Penyediaan Tempat dan/ atau Waktu

Obyek PPN: Penyerahan jasa penyediaan waktu dan/atau tempat dalam media lain 
Terhutangnya: Saat penyera-han, saat pembayaran, atau saat pemanfaatan

Dasar Pengenaan: Penggantian, termasuk semua biaya yang diminta atau seharusnya diminta oleh Penyelenggara Online Marketplace karena penyerahan JKP tersebut. Contoh: Penggantian, Monthly Fixed Fee, Rent Fee, Registration Fee, Fixed Fee, dan Subscription Fee.

2) Penjualan Barang dan/atau Jasa Obyek PPN: Penyerahan BKP dan/atau JK

Terhutangnya: Saat pembaya-ran

Dasar Pengenaan: Harga Jual, Penggantian, dan/atau Nilai Ekspor, termasuk semua biaya yg diminta atau seharusnya diminta oleh Online Market place Merchant karena penyerahan BKP dan/atau JKP tersebut. Contoh: Harga Jual, Penggantian, dan/atau Nilai Ekspor, biaya pengiriman, dan biaya asuransi.

3) Penyetoran Hasil Penjualan kepada Online Marketplace Merchant oleh Penyelenggara Online Marketplace Obyek PPN: Penyerahan jasa perantara pembayaran

Terhutangnya: Saat penyera-han, saat pembayaran, atau saat pemanfaatan

Dasar Pengenaan: Penggantian, termasuk semua biaya yang diminta atau seharusnya diminta oleh Penyelenggara Online Marketplace karena penyerahan JKP tersebut. Contoh: Penggantian, biaya settlement, dan fee penggunaan kartu kredit/kartu debit/internet banking.

\section{Classified Ads}

a. Pengenaan PPh dari Transaksi Classified Ads berkaitan dengan Jasa Penyediaan Tempat dan/atau Waktu
Obyek PPh: Penghasilan dari jasa penyediaan tempat dan/atau waktu dalam media lain untuk penyampaian informasi merupakan objek PPh yang wajib dilakukan pemotongan PPh Pasal 23, Pasal 21, atau Pasal 26

Subyek Pajak: Orang pribadi atau badan yang memperoleh penghasilan dari jasa penyediaan tempat dan/atau waktu dalam media lain untuk penyampaian informasi

Tarif: Untuk pihak Penyeleng-gara Classified Ads sebagai penyedia jasa yang pengha-silannya tidak dikenai pajak yang bersifat final, tarif PPh Pasal 17 diterapkan atas Penghasilan Kena Pajak Pemotongan: Apabila Peng-iklan sebagai pengguna jasa adalah Wajib Pajak Orang Pribadi atau Badan yang ditunjuk sebagai pemotong PPh, maka pengguna jasa tersebut wajib melakukan pemotongan PPh Pasal 23, Pasal 21, atau Pasal 26

b. Pengenaan PPN dari Transaksi Classified Ads berkaitan dengan Jasa Penyediaan Tempat dan/atau Waktu

Obyek PPN: Penyerahan jasa penyediaan waktu dan/atau tempat dalam media lain (termasuk kemungkinan jasa tersebut diserahkan secara Cuma-cuma) Terhutangnya: Saat penyera-han, saat pembayaran, atau saat pemanfaatan

Dasar Pengenaan: Penggantian, termasuk semua biaya yg diminta atau seharusnya diminta oleh Penyelenggara Classified Ads karena penyerahan JKP tersebut. Contoh: Penggantian dan transaction fee. Dalam hal JKP tersebut diserahkan secara Cuma-cuma, DPP-nya adalah Penggantian dikurangi laba kotor.

3. Daily Deals

a. Pengenaan PPh dari Transaksi Daily Deals

1) Jasa Penyediaan Tempat dan/ atau Waktu 
Obyek PPh: Penghasilan dari jasa penyediaan tempat dan/atau waktu dalam media lain untuk penyampaian informasi merupakan objek PPh yang wajib dilakukan pemotongan PPh Pasal 23, Pasal 21, atau Pasal 26

Subyek Pajak: Orang pribadi atau badan yang memperoleh penghasilan dari jasa penyediaan tempat dan/atau waktu dalam media lain untuk penyampaian informasi

Tarif: Untuk pihak Penyelenggara Daily Deals sebagai penyedia jasa yang penghasilannya tidak dikenai pajak yang bersifat final, tarif PPh Pasal 17 diterapkan atas Penghasilan Kena Pajak

Pemotongan: Apabila Merchant Daily Deals sebagai pengguna jasa adalah Wajib Pajak Orang Pribadi atau Badan yang ditunjuk sebagai pemotong PPh, maka pengguna jasa tersebut wajib melakukan pemotongan PPh Pasal 23, Pasal 21, atau Pasal 26

2) Penjualan Barang dan/atau Jasa

Obyek PPh: Penghasilan dari penjualan barang dan/atau penyediaan jasa merupakan objek PPh

Subyek Pajak: Orang pribadi atau badan yang memperoleh penghasilan dari jasa penyediaan tempat dan/atau waktu dalam media lain untuk penyampaian informasi

Tarif: Untuk Merchant Daily Deals sebagai penjual barang atau penyedia jasa yang penghasilannya tidak dikenai pajak yang bersifat final, tarif PPh Pasal 17 diterapkan

Pemotongan: Apabila pembeli barang atau pengguna jasa adalah Wajib Pajak Orang Pribadi atau Badan yang ditunjuk sebagai pemotong/ pemungut PPh, maka Pembeli barang atau pengguna jasa tersebut wajib melakukan pemotongan/pemungutan PP
3) Penyetoran Hasil Penjualan kepada Daily Deals Merchant Oleh Penyelenggara Daily Deals

Obyek PPh: Penghasilan dari jasa perantara pembayaran merupakan objek PPh yang wajib dilakukan pemotongan PPh Pasal 23, Pasal 21, atau Pasal 26

Subyek Pajak: Orang pribadi atau badan yang memperoleh penghasilan dari jasa perantara pembayaran

Tarif: Untuk pihak Penyeleng-gara Daily Deals sebagai penyedia jasa yang pengha-silannya tidak dikenai pajak yang bersifat final, tarif PPh Pasal 17 diterapkan atas Penghasilan Kena Pajak

Pemotongan: Apabila Merchant Daily Deals sebagai pengguna jasa adalah Wajib Pajak Orang Pribadi atau Badan yang ditunjuk sebagai pemotong PPh, maka pengguna jasa tersebut wajib melakukan pemotongan PPh Pasal 23, Pasal 21, atau Pasal 2

b. Pengenaan PPN dari Transaksi Daily Deals

a. Jasa Penyediaan Tempat dan/ atau Waktu

Obyek PPN: Penyerahan jasa penyediaan waktu dan/atau tempat dalam media lain

Terhutangnya: Saat penyera-han, saat pembayaran, atau saat pemanfaatan

Dasar Pengenaan: Penggantian, termasuk semua biaya yg diminta atau seharusnya diminta oleh Penyelenggara Penyelenggara Daily Deals karena penyerahan JKP tersebut.

b. Penjualan Barang dan/atau Jasa

Obyek PPN: Penyerahan BKP dan/atau JKP

Terhutangnya: Saat pembayaran

Dasar Pengenaan: Harga Jual, Penggantian, dan/atau Nilai Ekspor, termasuk semua biaya yg diminta 
atau seharusnya diminta oleh Daily Deals Merchant

c. Penyetoran Hasil Penjualan kepada Daily Deals Merchant Oleh Penyelenggara Daily Deals

Obyek PPN: Penyerahan jasa perantara pembayaran

Terhutangnya: Saat penyera-han, saat pembayaran, atau saat pemanfaatan.

Dasar Pengenaan: Penggantian, termasuk semua biaya yang diminta atau seharusnya diminta oleh Penyelenggara Daily Deals karena penyerahan JKP tersebut. Contoh: Penggantian, biaya settlement, dan fee penggunaan kartu kredit/kartu debit/internet banking.

\section{Online Retail}

a. Pengenaan PPh dari Transaksi Online Retail berkaitan dengan Penjualan Barang dan/atau Jasa

Obyek PPh: Penghasilan dari penjualan barang dan/atau penyediaan jasa

Subyek Pajak: Orang pribadi atau badan yang memperoleh penghasilan dari penjualan barang dan/atau penyediaan jasa

Tarif: Untuk pihak Penyeleng-gara Online Retail (sekaligus Merchant) sebagai penjual barang atau penyedia jasa yang penghasilannya tidak dikenai pajak yang bersifat final, tarif PPh Pasal 17

Pemotongan: Apabila pembeli barang atau pengguna jasa adalah Wajib Pajak Orang Pribadi atau Badan yang ditunjuk sebagai pemotong/ pemungut PPh, maka Pembeli barang atau pengguna jasa tersebut wajib melakukan pemotongan/pemungutan PPh

b. Pengenaan PPN dari Transaksi Online Retail

Obyek PPN: Penyerahan BKP dan/atau JKP
Terhutangnya: Saat penyera-han, saat pembayaran, atau saat pemanfaatan

Dasar Pengenaan: Harga Jual, Penggantian, dan/atau Nilai Ekspor, termasuk semua biaya yg diminta atau seharusnya diminta oleh Penyelenggara Online Retail karena penyerahan BKP dan/atau JKP tersebut. Contoh: Harga Jual, Penggantian, dan/atau Nilai Ekspor, biaya pengiriman, dan biaya asuransi

Dalam keempat model transaksi $e$ commerce ini, ada pembayaran imbalan atau penghasilan karena jual-beli barang/atau jasa yang merupakan objek pajak Pajak Penghasilan (PPh) dan Pajak Pertambahan Nilai (PPN) yang akan dikenakan pajak menurut aturan perpajakan yang berlaku.

Dampak yang harus diperhatikan oleh otoritas pajak jika memasukkan dalam aturan pajak penghasilan yaitu berkaitan dengan sifatnya yang mobile (tidak mempunyai tempat tetap) karena layanannya digital. Berbeda dengan Ekonomi tradisional (konvensional) yang mempunyai bentuk usaha tetap dan mempunyai tempat secara fisik. Lokasi fisik, barang dan jasa yang diproduksi dapat menandakan kahadiran fisiknya (bentuk usaha tetap) dan kehadiran fisiknya dapat digunakan untuk menentukan di mana pajak harus dibayar. Sedangkan di ekonomi digital hampir disemua rantai pasokan perdagangan dilakukan secara virtual tanpa kehadiran fisik. Sifat yang demikian, tempat tinggal yang tetap, tidak lagi di perlukan untuk menghasilkan pendapatan (Harpaz 2014; Hadzhieva 2016). Selain itu anonimitas data pelaku ekonomi digital yang disebabkan oleh sulitnya mengetahui lokasi, pemilik, dan mudahnya membuka dan menutup usaha. Hal ini sesuai dengan pernyataan Mentri keuangan Indonesia Sri Mulyani yang menyatakan model perpajakan tradisional yang didasarkan pada keberadaan fisik suatu perusahaan (physical presence) dinilai sudah tidak lagi relevan. model perpajakan baru yaitu dengan 
Yanis Ulul Az'mi: Perpajakan di Era...

menggunakan pendekatan kegiatan ekonomi (significant economic presence).

Masalah yang timbul dengan adanya ekonomi digital yaitu kesulitan untuk memungut PPN (Pajak Pertambahan Nilai) pada perdagangan lintas batas dalam jasa dan juga barang tidak berwujud. Tantangannya yaitu kesulitan mengidentifikasi perusahaan dalam ekonomi digital karena tidak adanya jejak kertas sama sekali, menentukan jumlah pajaknya, dan meningkatnya kemampuan untuk menyembunyikan pendapatan dan asset diluar negeri (Hadzhieva 2016). Masalah selanjutnya yaitu Bagaimana petugas pajak memperlakukan pekerja dalam bidang ini tidak jelas. Contohnya apakah pekerja taksi online, transportasi mobil, atau atau aplikasi seluler pengirim makanan (gofood), pengemudi menggunakan mobilnya sendiri (Grab, GoCar) dianggap sebagai karyawan atau pekerja mandiri (self-employment independent).

\section{Perpajakan di India}

Selama beberapa tahun, India berusaha mengubah cara perdagangannya. Pertumbuhan sektor e-commerce yang sebagian besar didorong oleh teknologi yang cepat dan kemudahan akses internet, sehingga konsumen online yang ada di India meningkat. Karena revolusi digital ini, sektor e-commerce di India telah meningkat empat kali lipat pada tahun 2009.
Model bisnis e-commerce mendukung kebijakan pemerintah, yaitu "Make in India" dan "Digital India". Model bisnis ini menyediakan pekerjaan bagi beberapa ribu anak muda. Selain itu bisnis ini juga memiliki dampak yang positif pada beberapa indutri lain seperti bisnis kendaraan komersial, layanan telpon dan internet, serta perbankkan. Industri ini tumbuh pada tingkat (CAGR) lebih dari 35 persen. Pertumbuhan disektor e-commerce telah menimbulkan berbagai masalah pajak. Oleh karena itu pemerintah India menerapkan aturan pajak terkait e-commerce yaitu Finance Act 2016 dalam Chapter VIII yang berjudul "Equalisation Levy" berlaku sejak 1 Juni 2016.

Penerapan pajak e-commerce di India menerapkan jenis pungutan lain di luar Pajak Penghasilan (PPh). India menerapkan skema Equalization Levy Rules (EQL) yaitu pajak yang berada di luar lingkup pajak penghasilan yang dipungut atas imbalan yang diterima atau seharusnya diterima atas jasa-jasa tertentu yang diatur pada peraturan EQL. EQL dikenakan terhadap pembayaran dari Subyek Pajak Dalam Negeri (SPDN) kepada Subyek Pajak Luar Negeri (SPLN) yang memenuhi ambang batas. Penerapan ini dinilai bisa mengantisipasi penghindaran pajak. Walaupun menurut Maulavan (2018) skema ini memiliki kelemahan. Hal ini karena EQL masuk di dalam kategori penerimaan negara bukan pajak (PNBP) sehingga pemungutannya tidak bisa meningkatkan kepatuhan pajak. 


\begin{tabular}{|c|c|c|c|}
\hline Particulars & Section & Rule & Explanation \\
\hline $\begin{array}{l}\text { Computation } \\
\text { and payment }\end{array}$ & $\begin{array}{l}\text { Section } 165 \\
\text { A } 166\end{array}$ & $\begin{array}{l}\text { Rule } 3 \text { and } \\
\text { Rule } 4\end{array}$ & $\begin{array}{l}\text { Equalisation levy of } 6 \% \text { to be deducted from } \\
\text { amounts paid to a non-resident not having any } \\
\text { permanent establishment in India, on specified } \\
\text { services }{ }^{*} \text {. Amount deducted during a month is } \\
\text { to be deposited with RBI or SBI before seventh day } \\
\text { of the following month. }\end{array}$ \\
\hline $\begin{array}{l}\text { Furnishing of } \\
\text { statement of } \\
\text { specified services } \\
\text { / annual return }\end{array}$ & Section 167 & $\begin{array}{l}\text { Rule } 5 \text { and } \\
\text { Rule } 6\end{array}$ & $\begin{array}{l}\text { The statement of specified service is required to be } \\
\text { furnished electronically in Form No. } 1 \text { on or before } 30^{\text {th }} \\
\text { June immediately following that financial year. }\end{array}$ \\
\hline $\begin{array}{l}\text { Processing of } \\
\text { statement of } \\
\text { specified services }\end{array}$ & Section 168 & Rule 7 & $\begin{array}{l}\text { Where any levy, interest or penalty is payable } \\
\text { under the provisions, a notice of demand specified in } \\
\text { Form No. } 2 \text { shall be served upon the taxpayer. }\end{array}$ \\
\hline $\begin{array}{l}\text { Filing of appeal } \\
\text { against the penalty } \\
\text { order before the } \\
\text { Commissioner of } \\
\text { Income-tax } \\
\text { (Appeals) [CIT(A)] }\end{array}$ & Section 174 & Rule 8 & $\begin{array}{l}\text { An appeal against the penalty order shall be } \\
\text { electronically filed before the CIT(A) in the } \\
\text { prescribed Form No. } 3 \text { within } 30 \text { days of receipt of the } \\
\text { penalty order. Further, a sum of INR } 1,000 \text { is } \\
\text { required to be deposited as appeal filing fee. }\end{array}$ \\
\hline $\begin{array}{l}\text { Filing of appeal } \\
\text { before the Income- } \\
\text { tax Appellate } \\
\text { Tribunal (Tribunal) }\end{array}$ & Section 175 & Rule 9 & $\begin{array}{l}\text { An appeal against the order of the } \mathrm{CIT}(\mathrm{A}) \text { has to } \\
\text { be filed in triplicate with the Tribunal within } 60 \text { days } \\
\text { of date of receipt of the order of CIT(A) in the } \\
\text { prescribed Form No. } 4 \text {. Further, a sum of INR } 1,000 \text { is } \\
\text { required to be deposited as appeal filing fee. }\end{array}$ \\
\hline
\end{tabular}

Gambar 1. Ringkasan tentang Equalisation Levy Rules

Mekanisme penerapannya adalah dikenakan dengan tarif 6 persen dari nilai kotor imbalan yang dibayarkan oleh SPDN India atau BUT subjek pajak luar negeri di India yang membayarkan imbalan atas jasa tertentu kepada SPLN India untuk transaksi antar bisnis (B2B) yang melebihi batas tertentu. Jenis jasa yang tercakup dalam EQL yaitu Jasa periklanan online, jasa penyediaan tempat untuk iklan online, dan jasa lainnya yang dapat ditentukan di kemudian hari (Gumilar 2017).

\section{Perpajakan di Inggris}

Pada tahun 2014, Diverted Profit Tax (DPT) akan diperkenalkan sebagai skema pajak baru di Inggris. Hal ini dapat dilihat pada Autumn Statement 2014 - corporate tax overview news item. Undang-undang FA 2015, ss 77 - 116 dan Sch 16. Dengan menerapkan skema DPT pemerintah berharap akan mencegah beberapa perusahaan multinasional yang menerapkan Teknik perencanaan pajak secara agresif untuk mengalihkan keuantungannya dari Inggris, sehingga tujuan perusahaan untuk meminimalkan tagihan pajak perusahaan akan tercapai.

DPT diterapkan pada laba yang dialihkan perusahaan kena pajak untuk periode akuntansi jika dalam situasi dibawah ini, FA 2015, s 77 (2):

1. Pungutan pada perusahaan yang ada di Inggris dimana transaksi dalam rantai pasokan global yang melibatkan entitas pajak rendah yang tidak memiliki substansi ekonomi, atau pengaturan yang memiliki tujuan utama untuk menghindari biaya pajak korporasi Inggris (section 80 charge). Pungutan DPT diberlakukan antara perusahaan yang dimiliki oleh penduduk Inggris dengan relasinya, yang mengakibatkan perusahaan yang dimiliki penduduk Inggris dapat melakukan pengurangan pajak secara signifikan dibandingkan dengan kenaikan pajak untuk relasinya (tax mismatch). Dengan adanya skema ini maka DPT dapat berlaku dalam kasus-kasus dimana seluruh perusahaan 
yang di Inggris yang terlibat dengan lawannya yaitu perusahaan multinasional.

2. Pungutan pada perusahaan non-Inggris dinama entitas atau transaksinya tidak memiliki substansi ekonomi (section 81 charge). Di mana DPT diberlakukan ketika perusahaan yang bukan warga negara Inggris melakukan perdagangan di Inggris melalui perusahaan permanen (PE) dan situasi pertama di (1) di atas akan berlaku untuk PE tersebut jika merupakan perusahaan residen di Inggris.

3. Pungutan pada perusahaan non-Inggris yang menghindari adanya pajak yang dapat dikenakan di Inggris (section 86 charge). Pungutan DPT diberlakukan ketika seseorang melakukan kegiatan di Inggris sehubungan dengan penjualan barang, layanan, atau properti lainnya oleh perusahaan yang bukan penduduk Inggris atau perusahaan residen non-Inggris.

HM Revenue and Customs (HMRC) Ditjen pajak akan mengeluarkan pemberitahuan kepada wajib pajak dimana dari ketiga situasi yang dijelaskan diatas merupakan dasar jumlah tagihan, periode akuntansi yang terkait dengan tagihan dan siapa yang bertanggung jawab untuk membayar DPT. Setelah melakukan pemberitahuan, HMRC akan melakukan peninjauan terhadap jumlah yang dikenakan. Peninjuan akan dilakukan selama periode 12 bulan dimulai sehari setelah periode 30 hari tanggal pemberitahuan dikeluarkan. HRMC dapat mengeluarkan pemberitahuan lebih lanjut selama peninjauan 12 bulan, untuk mengenakan pungutan tambahan DPT masih ada yang kurang.

Menurut Direktur Pajak Internasional Ditjen Pajak John Hutagaol, Diverted Profit Tax (DPT) adalah salah satu anti avoidance rule yang diterapkan untuk mencegah praktik penghindaran

pajak dengan melakukan artificial Permanent Establishment yang dapat berakibat negara di mana kegiatan ekonomi berlangsung tidak mendapatkan hak pemajakan atas penghasilan yang timbul. DPT ini membuat perusahaan over the top (OTT) seperti Google dan Facebook harus membayar pajak. Skema itu memungkinkan Inggris memungut pajak atas laba atau royalti setelah dialihkan ke negara lain yang memiliki aturan perpajakan yang longgar.

Selain perusahaan terkait dengan internet yang menjual barang dan jasa kepada pelanggan di Inggris, jenis pekerjaan yang dikenakan DPT yaitu:

1. Penjualan dan pemasaran, di mana tim pemasaran yang berasal di Inggris dan menegosiasikan penjualan tetapi kontrak diselesaikan di luar negeri

2. Layanan manajemen, di mana perusahaan Inggris mempekerjakan eksekutif yang mempunyai peran kunci dalam menegosiasikan atau mengevaluasi kesepakatan dengan pihak ketiga

3. Pengembangan IP Inggris, di mana perusahaan Inggris telah menjual IP-nya kepada afiliasi atau perusahaan Inggris mungkin melakukan kontrak layanan R\&D untuk afiliasi, kegiatan penjualan dan pemasaran yang berkaitan dengan IP yang dilakukan di Inggris.

4. Penjualan dan penyewaan properti, di mana real estat yang ada di Inggris dimiliki oleh afiliasi asing dan disewakan kepada afiliasi Inggris.

5. Penyewaan peralatan atau kapal, di mana perusahaan Inggris menyewa peralatan dari afiliasi.

\section{Subyek DPT}

Undang-undang DPT ditujukan untuk perusahaan multinasional yang mengatur untuk mengalihkan keuntungan di luar negeri untuk menghindari pajak yang ada di Inggris. 
Tabel 1. Perpajakan di Beberapa Negara

\begin{tabular}{|c|c|c|c|c|}
\hline Negara & Penerapan & Subyek & Tarif & DPP \\
\hline India & $\begin{array}{l}\text { Equalization } \\
\text { Levy Rules } \\
\text { (EQL) }\end{array}$ & $\begin{array}{l}\text { Pembayaran dari SPDN } \\
\text { kepada SPLN }\end{array}$ & $6 \%$ & $\begin{array}{l}\text { nilai kotor imbalan } \\
\text { (yang dibayarkan atas } \\
\text { transaksi antar bisnis } \\
\text { (business-to-business) } \\
\text { yang melebihi batas } \\
\text { tertentu). }\end{array}$ \\
\hline Australia & $\begin{array}{l}\text { Diverted } \\
\text { Provit Tax } \\
\text { (DPT) }\end{array}$ & $\begin{array}{l}\text { Perusahaan SPLN yang } \\
\text { melakukan transfer } \\
\text { keuntungan kepada } \\
\text { entitas di luar Australia }\end{array}$ & $10 \%$ & $\begin{array}{l}\text { Jumlah laba yang } \\
\text { dianggap telah } \\
\text { dialihkan SPLN }\end{array}$ \\
\hline UK & $\begin{array}{l}\text { Diverted } \\
\text { Provit Tax } \\
\text { (DPT) }\end{array}$ & Perusahaan SPLN & $19 \%$. & $\begin{array}{l}\text { Keuntungan yang } \\
\text { dialihkan (diverted } \\
\text { profits) oleh } \\
\text { perusahaan }\end{array}$ \\
\hline $\begin{array}{l}\text { Korea } \\
\text { Selatan }\end{array}$ & $\begin{array}{l}\text { Pajak } \\
\text { Pertambahan } \\
\text { Nilai }\end{array}$ & $\begin{array}{l}\text { setiap perusahaan yang } \\
\text { melakukan transaksi, } \\
\text { berapapun nilainya, } \\
\text { walaupun perusahaan } \\
\text { tersebut tidak memiliki } \\
\text { perwakilan bisnis, } \\
\text { perusahaan tersebut } \\
\text { akan dianggap berada di } \\
\text { wilayah Korea Selatan }\end{array}$ & $10 \%$ & $\begin{array}{l}\text { Nilai Transaksi, } \\
\text { dibayarkan setiap tiga } \\
\text { bulan ke Woori Bank, } \\
\text { harus menggunakan } \\
\text { mata uang Won }\end{array}$ \\
\hline Cina & $\begin{array}{l}\text { Pajak } \\
\text { Pertambahan } \\
\text { Nilai }\end{array}$ & $\begin{array}{l}\text { Barang yang dijual via e- } \\
\text { commerce }\end{array}$ & $\begin{array}{c}\text { PPN } 2 \% \\
\text { selama sekian } \\
\text { tahun, PPN } 5 \\
\text { \% dalam } \\
\text { sekian } \\
\text { periode }\end{array}$ & Nilai Transaksi \\
\hline Indonesia & $\begin{array}{l}\text { Mengikuti } \\
\text { aturan PPh } \\
\text { dan PPN }\end{array}$ & & & \\
\hline
\end{tabular}

Sumber: diolah dari beberapa sumber

\section{Tarif DPT}

Penerapan DPT di Inggris yaitu dikenakan dengan tarif $25 \%$ pada tahun 2015 dan 2016 sementara itu ditahun 2017 dikenakan sebesar $19 \%$. Tarif pajak ini lebih besar dari pada tarif pajak yang bersifat umum, dan dibayar terlebih dahulu walaupun Wajib Pajak (WP) mengajukan banding ke Pengadilan (Tribunal). DPT dikenakan atas keuntungan yang dialihkan (diverted profits) oleh perusahaan yang merupakan subyek pajak luar negeri Inggris dan akan dikenakan secara official assessment terhadap WP tersebut bila WP itu tidak patuh pada tahun berikutnya (https://cita.or.id 2017), sehingga penerapan DPT di Inggris membawa dampak positif yaitu peningkatan pajak penghasilan badan dan perubahan skema tranfer pricing perusahaan tanpa intervensi dari HM Revenue and Customs (HMRC) Ditjen Pajak. 
Yanis Ulul Az'mi: Perpajakan di Era...

\section{PENUTUP}

\section{SIMPULAN}

Munculnya ekonomi digital telah mengubah cara berbisnis yang semula konvensional menjadi serba digital (online). Ekonomi digital mempunyai peran yang signifikan bagi pertumbuhan ekonomi dunia, terbukti dengan banyaknya pendapatan yang diperoleh dari transaksi e-commerce. Hal ini akan membawa dampak dalam perpajakan yang ada di negara-negara tersebut. Oleh karena itu pemerintah setempat harus mengatur perpajakan terkait dengan transaksi yang akan ditimbulkan. Pemerintah India menerapkan skema Equalization Levy Rules (EQL) yang dikategorikan sebagai PNBP (Penerimaan Negara Bukan Pajak). Sementara di UK menerapkan skema Diverted Provit Tax (DPT). Sedangkan Indonesia belum ada aturan yang lebih spesifik, hanya ada Surat Edaran (SE) yang mengatur Penegasan Ketentuan Perpajakan Atas Transaksi e-Commerce yaitu $\mathrm{SE} / 62 / \mathrm{PJ} / 2013$ peraturan pajak e-commerce mengikuti undang-undang pajak penghasilan dan pajak pertambahan nilai.

\section{SARAN}

Adanya ekonomi digital menimbulkan banyak tantangan bagi pembuat kebijakan. Pembuat kebijakan harus memperhatikan perubahan dan perkembangan apa yang akan diatur. Mengkaji ulang nomenklatur bentuk usaha tetap (BUT) agar perusahaan yang menjalankan bisnis digital (online) bisa tercakup di dalamnya atau membuat skema pajak seperti yang dilakukan Inggris dan India. Karena banyaknya arus perdagangan lewat media sosial membuat pemerintah kesulitan mendata sehingga pemerintah harus membuat aturan terkait dengan $E$ Commerce, dimana saling melibatkan antar instansi pemerintah, yaitu Kementerian Teknologi Informasi, Kementerian Keuangan dan juga Lembaga keuangan untuk mendeteksi transaksi E-Commerce.

\section{REFERENSI}

Acharjee, M. (2018). International Taxation In India - Recent Developments \& Outlook (Part - I). Tax Bulletin August, Vol (22).

Anggraeni, R. (2018). Sri Mulyani: Butuh Model Perpajakan Baru di Era Ekonomi Digital. Tersedia di https://ekbis.sindonews.com/read/12 91744/33/sri-mulyani-butuh-modelperpajakan-baru-di-era-ekonomidigital-1521700129 [Diakses pada tanggal 19 November 2018].

Asosiasi Penyelenggara Jasa Internet Indonesia. (2016). Data Survey Pengguna Internet Indonesia. Tersedia di https://www.apiii.or.id [Diakses pada tanggal 20 November 2018].

Center for Indonesia Taxation Analysis. (2017). DJP Kaji Cara Inggris Pajaki Google Facebook DII. Tersedia di https://cita.or.id/news/citax/djp-kajicara-inggris-pajaki-google-facebookdII/ [Diakses pada tanggal 19 November 2018].

Deloitte. (2017). Diverted Profits Tax: how does it impact you?. Tersedia di https://www2.deloitte.com/au/en/pa ges/tax/articles/diverted-profitstax.html [Diakses pada tanggal 28 Januari 2019].

Gumelar, G. (2017). Berguru dari Negara Lain Demi Tarik Pajak e-Commerce. Tersedia di https://www.cnnindonesia.com/ekon omi/20171129101646-532-

258860/berguru-dari-negara-laindemi-tarik-pajak-e-commerce [Diakses pada tanggal 28 Januari 2019].

Hadzhieva, E. (2016). Tax Challenges in the Digital Economy. Tersedia di http://www.europarl.europa.eu/RegD ata/etudes/STUD/2016/579002/IPOL STU(2016)579002_EN.pdf

Harpaz, J. (2014). DigitalEconomy Raises Serious Questions for Global Tax Policy. Tersedia di 
https://www.forbes.com/sites/joehar paz/2014/03/12/digital-economyraises-serious-questions-for-globaltax-policy/\#3d0adc8757ef [Diakses pada tanggal 28 Januari 2019].

HM Revenue and Customs. Consultation draft DIVERTED PROFITS TAX UK Government. Diakses https://assets.publishing.service.gov.u k/government/uploads/system/uploa ds/attachment data/file/385741/Dive rted Profits Tax.pdf

India, The Institute of Chartered Accountant. (2012). Taxation of E-Commerce Transaction. Tersedia di http://idtc.icai.org/publications.php [Diakses pada tanggal 19 November 2018].

Ismail, Muhammad I. (2017). Inilah 7 Situs Raksasa E Commerce Di Dunia. Tersedia di https://resellerlaris.id/infobisnis/17/inilah-7-situs-raksasa-ecommerce-di-dunia [Diakses pada tanggal 19 November 2018].

Kominfo. (2017). Penetrasi dan Perilaku Pengguna Internet Indonesia. Tersedia di

https://web.kominfo.go.id/sites/defau It/files/Laporan\%20Survei\% 20APJII_2017_v1.3.pdf [Diakses pada tanggal 19 November 2018].

Juswanto, et al. (2017). Fair Taxation in the Digital Economy. ABDI Institute

Katadata. (2018). 4 Miliar Penduduk Bumi Telah Terkoneksi Internet. Tersedia di https://databoks.katadata.co.id/datap ublish/2018/07/23/4-miliarpenduduk-bumi-telah-terkoneksiinternet [Diakses pada tanggal 19 November 2018].

Mahatma, R. 2016. Data Statistik Mengenai Pertumbuhan pangsa pasar ECommerce di Indonesia Saai ini. Tersedia di https://buattokoonline.id/datastatistik-mengenai-pertumbuhan- pangsa-pasar-ecommerce-diindonesia-saat-ini/] [Diakses pada tanggal 19 November 2018].

Mardiasmo. (2011). Perpajakan Edisi Revisi 2011. Jogjakarta: Andi Jogjakarta.

Maulavan, A. (2018). Ini Aturan Pajak ECommerce di Beberapa Negara. Tersedia di https://klikpajak.id/iniaturan-pajak-e-commerce/ [Diakses pada tanggal 19 November 2018].

Okestories. (2018). Revolusi Industri 1.0-4.0 : Perkembangan Peradaban Manusia. Tersedia di http://okestories.net/revolusiindustri-1-0-4-0-perkembanganperadaban-manusia/ [Diakses pada tanggal 19 November 2018].

Organisation for Economic Co-operation and Development (OECD). (2005). Are the Current Treaty Rules for Taxing Business Profits Appropriate for ECommerce?: Final Report.

Raymond McLeod Jr. 2007. Management Information System. Printice Hall International Inc.: New Jersey

Republik Indonesia. Surat Edaran Direktur Jenderal Pajak Nomor: SE 62/PJ/2013 Tentang Penegasan Ketentuan Perpajakan Atas Transaksi ecommerce. Republik Indonesia. Undang-Undang No. 42 Tahun 2009 tentang Perubahan Undang-Undang No. 8 Tahun 1983 Tentang Pajak Pertambahan Nilai dan atau Penjualan atas Barang Mewah.

Republik Indonesia. Undang-Undang Nomor 36 Tahun 2008 tentang Perubahan Undang-UndangNo. 7 tahun 1984 tentang Pajak Penghasilan (PPh).

Sandhusen, R. (2008). Marketing. N.Y: Barron's Educational Series.

Tim Viva. (2018). 4 Tahap Revolusi Industri Sampai ke Era 4.0. Tersedia di https://www.viva.co.id/digital/digilife/ 1040470-4-tahap-revolusi-industrisampai-ke-era-4-0 [Diakses pada tanggal 19 November 2018]. 
Widagdo, Prasetyo B. (2018). Analisis perkembangan E-commerce dalam mendorong pertumbuhan ekonomi wilayah Indonesia. Tersedia di https://www.researchgate.net/public ation/308318863 Analisis Perkemban gan $\mathrm{E}-$

commerce Dalam Mendorong Pertu mbuhan Ekonomi Wilayah di Indon esia [Diakses pada tanggal 19 November 2018]. 